\title{
Alternatives to Sedum on green roofs: Can broad leaf perennial plants offer better 'cooling service'?
}

Article

Accepted Version

Blanusa, T., Vaz Monteiro, M. M., Fantozzi, F., Vysini, E., Li, Y. and Cameron, R. W.F. (2012) Alternatives to Sedum on green roofs: Can broad leaf perennial plants offer better 'cooling service'? Building and Environment, 59. pp. 99-106. ISSN 0360-1323 doi: https://doi.org/10.1016/j.buildenv.2012.08.011 Available at https://centaur.reading.ac.uk/29002/

It is advisable to refer to the publisher's version if you intend to cite from the work. See Guidance on citing.

To link to this article DOI: http://dx.doi.org/10.1016/j.buildenv.2012.08.011

Publisher: Elsevier

All outputs in CentAUR are protected by Intellectual Property Rights law, including copyright law. Copyright and IPR is retained by the creators or other copyright holders. Terms and conditions for use of this material are defined in the End User Agreement.

www.reading.ac.uk/centaur 
Central Archive at the University of Reading

Reading's research outputs online 


\section{Accepted Manuscript}

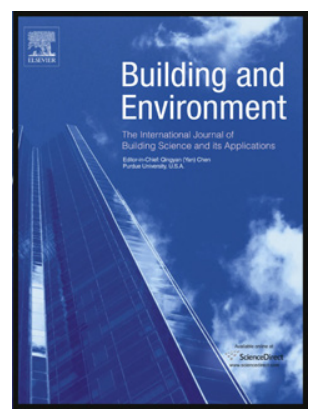

Alternatives to Sedum on green roofs: Can broad leaf perennial plants offer better 'cooling service'?

Tijana Blanusa, M. Madalena Vaz Monteiro, Federica Fantozzi, Eleni Vysini, Yu Li, Ross W.F. Cameron

PII: S0360-1323(12)00213-2

DOI: 10.1016/j.buildenv.2012.08.011

Reference: $\quad$ BAE 3210

To appear in: Building and Environment

Received Date: 29 March 2012

Revised Date: 13 August 2012

Accepted Date: 13 August 2012

Please cite this article as: Blanusa T, Madalena Vaz Monteiro M, Fantozzi F, Vysini E, Li Y, Cameron RWF, Alternatives to Sedum on green roofs: Can broad leaf perennial plants offer better "cooling service'?, Building and Environment (2012), doi: 10.1016/j.buildenv.2012.08.011.

This is a PDF file of an unedited manuscript that has been accepted for publication. As a service to our customers we are providing this early version of the manuscript. The manuscript will undergo copyediting, typesetting, and review of the resulting proof before it is published in its final form. Please note that during the production process errors may be discovered which could affect the content, and all legal disclaimers that apply to the journal pertain. 


\section{Highlights:}

- Of all the species tested, leaf surface temperature was lowest in Stachys, even when water was limited.

- On warm days, both Stachys and Sedum cooled the air above the substrate compared to bare soil.

- On several hot afternoons in the glasshouse Stachys provided more aerial cooling than other species.

- In outdoor conditions we recorded one incidence where Stachys provided additional localised aerial cooling.

- On a warm day, temperatures below Stachys and Sedum canopies were $11{ }^{\circ} \mathrm{C}$ and $4{ }^{\circ} \mathrm{C}$ lower than of bare soil. 
1 Alternatives to Sedum on green roofs: Can broad leaf perennial plants offer better 'cooling

2 service'?

3

4 Tijana BLANUSA ${ }^{\mathrm{a}, \mathrm{b}, ~ *}$, M. Madalena VAZ MONTEIRO ${ }^{\mathrm{b}}$, Federica FANTOZZI $^{\mathrm{c}}$, Eleni

$5 \quad$ VYSINI $^{\mathrm{b}}, \mathrm{Yu} \mathrm{LI}^{\mathrm{b}}$ and Ross W. F. CAMERON ${ }^{\mathrm{d}}$

6

$7 \quad{ }^{a}$ Plant Sciences Department, Royal Horticultural Society, Garden Wisley, Woking GU23

8 6QB, UK

$9{ }^{\mathrm{b}}$ School of Biological Sciences, University of Reading, Whiteknights, Reading RG6 6AS,

$10 \mathrm{UK}$

$11{ }^{\mathrm{c}}$ Department of Environmental Sciences 'G. Sarfatti', University of Siena, Via P.A. Mattioli

124,53100 Siena, Italy

$13{ }^{\mathrm{d}}$ Department of Landscape, University of Sheffield, Sheffield S10 2TN, UK

14 *Author for correspondence: tijanablanusa@ rhs.org.uk, Telephone: +44-(0)118-378-6467 


\section{Abstract}

17

18 Green roof plants alter the microclimate of building roofs and may improve roof insulation.

19 They act by providing cooling by shading, but also through transpiration of water through

20 their stomata. However, leaf surfaces can become warmer when plants close the stomata and

21 decrease water loss in response to drying substrate (typically associated with green roofs

22 during summers), also reducing transpirational cooling. By using a range of contrasting plant

23 types (Sedum mix - an industry green roof 'standard', Stachys byzantina, Bergenia cordifolia

24 and Hedera hibernica) we tested the hypothesis that plants differ in their 'cooling potential'.

25 We firstly examined how leaf morphology influenced leaf temperature and how drying

26 substrate altered that response. Secondly, we investigated the relationship between leaf

27 surface temperatures and the air temperatures immediately above the canopies (i.e. potential

28 to provide aerial cooling). Finally we measured how the plant type influenced the substrate

29 temperature below the canopy (i.e. potential for building cooling). In our experiments Stachys

30 outperformed the other species in terms of leaf surface cooling (even in drying substrate, e.g.

$315{ }^{\circ} \mathrm{C}$ cooler compared with Sedum), substrate cooling beneath its canopy (up to $12{ }^{\circ} \mathrm{C}$ ) and

32 even - during short intervals over hottest still periods - the air above the canopy (up to $1{ }^{\circ} \mathrm{C}$,

33 when soil moisture was not limited). We suggest that the choice of plant species on green

34 roofs should not be entirely dictated by what survives on the shallow substrates of extensive

35 systems, but consideration should be given to supporting those species providing the greatest

36 eco-system service potential. 


\section{7}

\section{Additional key words:}

39 Air cooling; building insulation; drought; leaf temperature; Stachys byzantina 40 


\section{1. Introduction}

42

43 Enhancing a city's green infrastructure is frequently thought of as a means to help address a

44 number of environmental problems associated with the built environment $[1,2]$. The ability

45 of urban vegetation to help mitigate urban heat island effects [3] and to reduce the energy

46 load on buildings [4] are two important ecosystem services that plants can provide. Globally,

47 urbanisation is still increasing and there is more pressure within the urban matrix for land to

48 be used for housing, business development and the associated infrastructure. Consequently,

49 the use of green roofs has been advocated, partially in an attempt to provide some urban

50 green space, without adding to the pressures on land at ground level. Even in countries which

51 traditionally have not suffered from extreme anti-cyclonic conditions ('heat-waves') such as

52 those in Northern Europe, there are concerns that a changing climate combined with urban

53 expansion will result in more frequent incidents of severely elevated temperatures [5]. The

54 use of urban greening is therefore advocated to help mitigate such events, and helps in part to

55 compensate for the lack of alternative cooling mechanisms more typical of warmer

56 Mediterranean climates e.g. lightly coloured buildings with high albedo, thick insulating

57 walls, shuttered windows, greater exploitation of prevailing cooling winds etc. [6].

58 In Northern Europe and indeed many other regions, vegetation is now considered to be a vital

59 component in reducing air temperatures at the city-wide scale $[7,8]$ as well as locally (e.g. [6,

60 9]). Plants provide a cooling influence by transpiration of water through their stomata [10],

61 but also through direct shading [11]. It has been claimed that green roofs harbour genuine

62 potential for urban temperature reduction [12], but the extent to which they contribute to

63 urban cooling compared to other vegetation types or landforms (e.g. street trees, urban forest,

64 parkland etc.) is unclear. Indeed, there is still some debate as to how micro-climates

65 associated with different types of urban vegetation actually influence climate at the larger 
66 urban scale [13]. At a more local level, it is acknowledged that low-growing terrestrial

67 vegetation (lawn grass particularly) can enhance aerial cooling, at least in comparison to 68 harder, more typical urban surfaces (asphalt, concrete, paving etc.) [14, 15]. However, the

69 evidence for green roofs providing significant air cooling remains limited [16]. Furthermore,

70 the ability of green roof plants to extract and transpire water may be considerably

71 compromised in the shallow, lithosol-like substrates used on green roofs compared to a

72 deeper profile, natural soil. Also, leaf surfaces are likely to become warmer when plants close 73 their stomata and decrease water loss in response to drying substrate [17].

75 Green roofs can help insulate buildings against thermal gain from solar radiation [18],

76 although it is often acknowledged that it is the depth of the substrate that determines the

77 extent of insulation more than the amount of vegetation [19]. However, the depth of green

78 roof substrate is often dictated in practice by the weight load placed on the roof (i.e. thinner

79 substrates are preferred from an engineering perspective). The extent to which the vegetation

80 can then provide additional cooling to the substrate, becomes an important practical and 81 research question.

82

83 Due to the drought prone and exposed nature of extensive and semi-extensive green roofs,

84 Sedum sp. (e.g. S. album, S. acre, etc.) with typical xerophytic characteristics are the most

85 widely used plant group [20]. Sedum sp. establish rapidly, provide good surface coverage and 86 are effective in decreasing storm water runoff while requiring low maintenance [21]. A

87 number of studies worldwide have investigated species alternative to Sedum, including bulbs

88 and grasses (e.g. in Germany [22]), small shrubs, grasses and ornamental perennials (e.g. in

89 Japan [23]), as well as species mixes that included succulents (e.g. in Canada, [24]) but only

90 two tested alternatives to Sedum in the UK climatic conditions [25, 26]. The focus of these 
91 studies has been on ecological function, particularly species survival and growth rates. The

92 results showed that there were alternatives to Sedum in terms of good surface coverage and

93 providing protection from water runoff, but there was little emphasis on other ecosystem

94 services, including cooling potential.

95

96 Since the priority for plant selection on extensive and semi-extensive green roofs has been

97 stress tolerance (with perhaps aesthetic quality being second), only limited attention has been

98 paid to a species' ability to provide cooling. Indeed, it had been suggested that Sedum and

99 other species currently used (and ones with similar morphological adaptations such as small /

100

narrow / succulent / hairy leaves with thick cuticle) are unlikely to offer substantial evapo-

101

transpirational (ETp) cooling, especially when the weather is hot and dry [27]. Furthermore,

102 reduced substrate moisture availability, frequently associated with green roofs, causes leaf

103 stomatal closure and a consequent warming of the leaf surface [28], but the extent of this

104 response is likely to differ between species. Depending on performance, some less stress

105 tolerant species may justify further investment required to support their establishment and

106 growth on roofs, by providing better cooling than 'traditional' green roof species. The

107 philosophy around plant selection should therefore change from solely 'what survives' to

108 'what provides the greatest ecosystem service' (i.e. cooling). This leads to three questions:

109 i. Are there species more effective than Sedum in regulating their own leaf temperatures

110 in hot weather?

111 ii. How does this relate to their ability to regulate air and surface (i.e. substrate)

112 temperatures adjacent to the plant?

113 iii. How would such species perform when conditions become sub-optimal, i.e. reduced

$114 \quad$ water availability?

115 
116 The aim of our research was to address these questions. By using a range of contrasting plant

117 types we wished to examine how leaf morphology influenced leaf temperature and how

118 decreasing substrate water availability (typically associated with green roofs in hot weather)

119 alters that response. Secondly, we wished to investigate the relationship between leaf surface

120 temperature and the temperature of the air immediately above the canopy (i.e. potential to

121 provide aerial cooling). The choice of height for measurements of air temperatures in our

122 experiment was driven by the hypothesis that differences in leaf temperatures could translate

123 in differences in air temperatures in the immediate vicinity of the plants; these could then be

124 utilised to influence positioning of air conditioning units within vegetation on a building

125 surface (e.g. lowering their energy consumption in a 'cooler' environment). Finally, a third

126 objective was to observe how plant type influenced the temperature of the substrate below the

127 canopy (i.e. potential for building cooling).

128

129 Due to its prevalence in practice we used a commercial Sedum mix matting in our

130 experiments to act as an industry standard (control) system. In comparison, monocultures of

131 three broad-leaved perennial plants: Bergenia cordifolia, Hedera hibernica and Stachys

132 byzantina were used to compare their thermodynamics to that of the Sedum mix. We

133 specifically chose broad-leaved species to test the hypothesis that these would have lower

134 leaf temperatures and perhaps lower surrounding air or substrate temperatures; earlier studies

135 have indicated that traits such as succulence, presence of leaf hairs etc. are involved in

136 regulating leaf temperature [29]. We also selected candidate species to reflect different

137 ecological backgrounds, on the basis that some e.g. Stachys (from a Mediterranean climate)

138 may possess a degree of drought tolerance and hence perhaps be the most amenable to green

139 roof culture, but at the same time are suitable for the UK climatic conditions [30]. 
141

142

143

144

145 Three broad-leaved, perennial species: Bergenia cordifolia (large, waxy leaves), Hedera

146 hibernica (leaves with thick epidermis, providing good cover) and Stachys byzantina (leaves

147 with light-coloured hairs) were compared to Sedum sp. mix (small, succulent leaves) in

148 Experiment 1, with Stachys and or Sedum sp. mix used in subsequent experiments.

149 Sedum was purchased as a commercially used 'Enviromat' matting system (Q Lawns,

150 Hockwold, Norfolk, UK) and represented a random mix of Sedum album, S. spurium, S. acre 151

152

153

154

155

156

157

158

159

160

161

162

163

164 and $S$. sexangulare. Other plant species were purchased from a commercial nursery as 1-year old plants in $250 \mathrm{ml}$ containers.

2.2. Experiment 1 . The effect of species and water availability on leaf stomatal conductance, $\underline{\text { leaf surface temperature and air temperature above the canopy (glasshouse conditions) }}$

\subsubsection{Experimental set-up}

On 3 June 2009, plants were planted into custom-made large containers (1.2 m (l) x $0.4 \mathrm{~m}(\mathrm{w})$ x $0.4 \mathrm{~m}(\mathrm{~h})$ ) filled to a depth of $0.2 \mathrm{~m}$ with commercial intensive green roof substrate(Shire Green Roof Substrates Ltd., Southwater, West Sussex, UK), to mimic a standard semiintensive green roof. The substrate had the following properties (as specified by the manufacturers): $\mathrm{pH}=8.5$, total pore volume $49-60 \%$, soil organic matter $9.2 \%$ and maximum water holding capacity $33.5 \%$.

There were six containers per species and an additional six with unplanted (bare) substrate.

165 Containers were organized in a randomised block design and located in a ventilated 
166 glasshouse; where minimal / night temperatures never fell below $15^{\circ} \mathrm{C}$ and maximal /

167 daytime temperatures were in the range $22-37{ }^{\circ} \mathrm{C}$, the $\mathrm{RH}$ in the compartment was around $16830 \%$ during daytime and $70 \%$ during the night. Twenty eight plants per container of Stachys 169 and Bergenia and eight plants of Hedera per container were planted to achieve $90 \%$ of initial 170 ground coverage. Sedum mat, with the root barrier layer removed, was laid on top of the 0.2 171 m deep substrate.

172

173

174

175

176

177

178

179

180

181

182

183

184

185

186

187

188

189

190

\subsubsection{Watering treatments}

At planting and daily until 9 June all containers were watered to container capacity; from 10 June 2009 until the end of the experiment 30 days later (10 July 2009) containers were either watered to achieve soil moisture content (SMC) $>0.25 \mathrm{~m}^{3} \mathrm{~m}^{-3}$ ('well-watered' treatment, three containers per species/substrate) or $<0.15 \mathrm{~m}^{3} \mathrm{~m}^{-3}$ ('under-watered'/‘dry' treatment). Preliminary experiments suggested that this SMC lead to stomatal closure and growth reduction, without affecting plant survival. Hand-watering was performed in late afternoon, daily or weekly, for 'well-watered' and 'dry' treatments, respectively.

\subsubsection{Plant and substrate measurements}

Substrate moisture content was measured twice weekly using SM200 probe (Delta-T Devices Ltd., Cambridge, UK) in five locations across the middle of the longer axis of each of the containers, close to a plant. Measurements were made between 09:00 and10:00 h (British Summer Time, BST).

Leaf stomatal conductance to water vapour $\left(g_{s}\right)$ was measured in all species apart from Sedum (where the leaves were too small and thick for the instrument's chamber), twice weekly between 10:00 and 15:00 h (BST) to follow SMC measurements, using AP4 porometer (Delta-T Devices Ltd., Cambridge, UK) on seven randomly selected plants (two leaves per 
191 plant) in each of the containers. Leaf stomatal conductance is measured as the rate of passage

192 of water vapour leaving a stomatal pore and is expressed in $\mathrm{mmol} \mathrm{m} \mathrm{m}^{-2} \mathrm{~s}^{-1}$.

193

194 Surface temperatures (plants and bare substrate) were measured by analysing Infra-Red

195 thermal images; the images were taken between 13:00 and 14:00 $\mathrm{h}$ (BST) at regular intervals

196 during the experiment to capture multiple days with similar and varying weather, using

197 Thermo Tracer TH7800 camera (NEC San-ei Instruments Ltd., Japan). Thermal images were

198 taken from the $30^{\circ}$ angle with respect to the vertical and $1 \mathrm{~m}$ distance from the container edge

199 and from $1.2 \mathrm{~m}$ height in all cases; nine areas of $50 \times 50 \mathrm{~mm}$ in the middle of each container

200 were analysed for their average temperature using the NS9200 Report Generator software

201 (NEC San-ei Instruments Ltd., Japan). Air temperature was measured at 30 min intervals at

202 fixed height $300 \mathrm{~mm}$ above the middle of the substrate surface for the duration of the

203 experiment using screened RHT2n sensors attached to a DL2e logger (Delta-T Devices Ltd.,

204 Cambridge, UK). The height of the sensor was dictated by the experimental design in

205 experiment 1, where the sensor was placed directly above the centre of the plant canopy and

$206100 \mathrm{~mm}$ above the height of the lip of the container the plants were grown in. This was

207 implemented to enable us to measure temperature at a fixed height above the ground, so that

208 we can compare absolute impact of the absence of vegetation / various types of vegetation

209 which inherently differs in canopy height. Preliminary evaluations indicated there was less

210 temporary fluctuation in temperatures at the $300 \mathrm{~mm}$ height when glasshouse doors or vents

211 were opened compared to higher positions; and lowering the sensors further, could result in

212 direct shading of a large proportion of the canopy. Prior to the start of measurements, in all

213 experiments, temperature sensors were compared by running them for $24 \mathrm{~h}$ in a controlled

214 environment room and found to be within $\leq 1 \%$ error of each other.

215 
216 2.3. Experiment 2. Comparisons between Sedum mix and Stachys byzantina: leaf surface

217 temperature and air temperature above the canopy (glasshouse conditions)

218

219 On 1 June 2010, Stachys byzantina was planted and Sedum matting was laid into containers 220 and two watering regimes were imposed, as described for Experiment 1 (Section 2.2.2.).

221 There were 10 containers for each of the plant covers and an additional 10 containers with 222 unplanted substrate. The experiment ran for approx. 3 weeks from 3-23 June 2010 and 223 measurements of SMC, surface and air temperature were made as described for Experiment 1 224 (Section 2.2.3). Additionally, measurements of $g_{s}$ were performed in both species with an 225 LCi portable open gas exchange system (ADC BioScientific Ltd., Hoddesdon, UK) with 226 ambient $\mathrm{CO}_{2}$ concentration at $385 \pm 5 \mathrm{~mm}^{3} \mathrm{dm}^{-3}$. During measurements, photosynthetic 227 photon flux density was supplemented to a minimum of $1000 \mu \mathrm{mol} \mathrm{m} \mathrm{m}^{-2} \mathrm{~s}^{-1}$ by an external (50 $228 \mathrm{~W}, 12 \mathrm{~V}$ ) halogen source. Measurements on seven plants per container (two leaves per plant) 229 were carried out between 10:00 and 15:00 h (BST).

230

2.4. Experiment 3. Comparisons between Sedum mix and Stachys byzantina: leaf surface temperature, air temperature above the canopy and ground surface cooling (outdoor

233 conditions)

234

235 An outdoor experiment was set up at the University of Reading, UK. Six plots, each 236 measuring $2.2 \mathrm{~m}(\mathrm{l}) \times 2.2 \mathrm{~m}(\mathrm{w}) \times 0.1 \mathrm{~m}(\mathrm{~d})$, were constructed at ground level using timber, 237 lined with polyethylene pond liner ( $0.75 \mathrm{~mm}$ thickness) and filled with John Innes No 2 238 substrate to $0.1 \mathrm{~m}$ depth. There were two plots for each of the surfaces: bare substrate, 239 Stachys byzantina and Sedum sp. matting. Vegetation was planted in September 2010 and by 240 the onset of the experiment (27 May 2011), plants covered 100\% of the plot surfaces; bare 
241 substrate was kept weed-free. Plots were rain-fed, but throughout the experiment the SMC

242 remained above $0.15 \mathrm{~m}^{3} \mathrm{~m}^{-3}$. The experiment commenced on 27 May 2011 and terminated on 2433 July 2011.

244 To increase the likelihood of detecting local air temperature differences outdoors, where there 245 is greater air mixing, screened temperature sensors RHT2n were placed at two heights on the 246 edge and in the centre of the plots. One sensor was placed in line with the plant canopy (20-

$24730 \mathrm{~mm}$ above the soil surface) surface and another $100 \mathrm{~mm}$ above the canopy The larger 248 planted area in this experiment $\left(4.84 \mathrm{~m}^{2}\right)$ compared to Experiment $1\left(0.48 \mathrm{~m}^{2}\right)$ enabled sensors 249 to be placed closer to the canopy than before, without affecting a proportionally large area of 250 the canopy through shade. Furthermore, in this experiment we were interested in using top of 251 the plant canopy, rather than the soil surface, as a 'reference point', to provide us with the 252 relative comparisons between plant species. Additionally, soil surface temperature beneath 253 the plants was measured by placing thermocouples (type Fenwal UUA32J2, in house 254 construction) $5 \mathrm{~mm}$ below the soil surface in the centre of all plots. Temperature was 255 measured at $5 \mathrm{~s}$ intervals and averaged every $10 \mathrm{~min}$. Measurements of leaf surface 256 temperature were by thermal imaging as described for Experiment 1 (section 2.2.3).

257 Additionally, anemometer (A 100R, Skye Instruments Ltd., Llandrindod Wells, UK) was 258 placed in the centre of the experimental area to monitor wind velocity at the same time as 259 temperature readings were recorded.

260 Substrate moisture content was measured twice weekly using SM200 probe (Delta-T Devices 261 Ltd., Cambridge, UK) between 09:00 and10:00 h (BST) in 12 locations evenly distributed 262 across every plot. Net total radiation (i.e. difference between incoming and outgoing/reflected 263 radiation) was measured on 3 June using net pyrradiometer CN1/919 (Middleton Solar, 264 Melbourne, Australia) attached to DT 500 Datataker logger (Omni Instruments, Dundee, 265 UK). The measurements were made between 11:30 and 12:30 h (BST), logging every $30 \mathrm{~s}$ for 
26615 minutes, $300 \mathrm{~mm}$ above one plot per each of the surfaces (bare soil, Sedum mix and

267 Stachys). During the same time period we recorded the surface temperatures of the surfaces

268 where net radiation measurements were made using the methodology described in Section

$269 \quad 2.2 .3$

270 Leaf area index (LAI) was measured at the end of the experiment by dividing the leaf area of

271 Stachys and Sedum (measured with Area Meter, Delta-T Devices Ltd., Cambridge, UK) by

272 the surface area from which the leaves were sampled (three samples per plot). For the

273 proportion of non-flat Sedum leaves (S. album and S. sexangulare) LAI was adjusted by

274 multiplying by $\mathrm{k}=0.5$, as suggested by Chen and Black [31].

275

276 2.5. Experiment 4. The role of leaf hairs in Stachys byzantina in regulating leaf temperature

277 (controlled environment cabinet)

278 Leaf hairs were removed on 21 March 2010 from both ab- and adaxial surfaces on ten young

279 fully expanded Stachys leaves from three containerised plants grown in the glasshouse, using

280 an electrical hair trimmer (D.D., Wahl, UK). The effectiveness of hair removal was measured

281 under the light microscope using five additional leaves per treatment; on average unshaved

282 leaf hairs were $2.19 \mathrm{~mm}$ long and the shaved ones were significantly shorter at $0.47 \mathrm{~mm}$

$283(\mathrm{LSD}=0.138 \mathrm{~mm})$. Three days after shaving, ten 'shaved' leaves along with ten unshaved

284 ('control') leaves were excised under water and placed immediately and into $25 \mathrm{ml}$ conical

285 flasks with $10 \mathrm{ml}$ water [32]. Vials with individual leaves were weighed and thermal images

286 of the leaves were taken; vials were then placed in the controlled environment cabinets for 24

$287 \mathrm{~h}$ (temperature $22{ }^{\circ} \mathrm{C}, 50 \% \mathrm{RH}$, light supplemented at $550 \mu \mathrm{mol} \mathrm{m} \mathrm{m}^{-2} \mathrm{~s}^{-1}$ ) and weighing and

288 imaging procedure repeated 2, 4, 6, 8 and $24 \mathrm{~h}$ after the start of the experiment. Leaf stomatal

289 conductance (five leaves per treatment @ 2, 4, 6, 8 and $24 \mathrm{~h}$ after the start of the experiment) 
290 and individual leaf areas (at the end of the experiment) were measured as described for

291 Experiments 2 (Section 2.3) and 3 (Section 2.4), respectively.

292

293

2.6. Statistical analysis

294 Data were analysed using GenStat ( $11^{\text {th }}$ Edition, Lawes Agricultural Trust, Rothamsted

295 Experimental Station, UK). Analysis of variance (ANOVA) was used to assess the effects of 296 different watering regimes and the plant species/surface on measured parameters; variance

297 levels were checked for homogeneity and values were presented as means with associated 298 least significant differences (LSD, $P=0.05)$.

299

300

\section{Results}

301

302 3.1. Experiment 1. The effect of species and water availability on leaf stomatal conductance,

303 leaf surface temperature and air temperature above the canopy (glasshouse conditions)

304 From day 4 of the experiment, significant differences in SMC were apparent between the 305 'well- watered' and 'dry' treatment plants and from day 10 the SMC was consistently at, or

306 below, $0.15 \mathrm{~m}^{3} \mathrm{~m}^{-3}$ in the 'dry' treatment (data not shown). Within both 'well- watered' and 307 'dry’ plants, SMC was similar between Stachys, Hedera and Bergenia and always higher in 308 those three species than in Sedum (data not shown).

309 Leaf stomatal conductance $\left(g_{s}\right)$ was consistently lower in the 'dry' treatment from day 14 . In

310 'well-watered' plants average $g_{s}$ values were $233.1 \mathrm{mmol} \mathrm{m}^{-2} \mathrm{~s}^{-1}$ for Stachys, $220.1 \mathrm{mmol} \mathrm{m}^{-2}$

$311 \mathrm{~s}^{-1}$ for Hedera and $217.0 \mathrm{mmol} \mathrm{m}^{-2} \mathrm{~s}^{-1}$ for Bergenia. Conversely, in the 'dry' treatment the

312 overall averages were 147. $\mathrm{mmol} \mathrm{m}^{-2} \mathrm{~s}^{-1}$ for Stachys; $98.8 \mathrm{mmol} \mathrm{m}^{-2} \mathrm{~s}^{-1}$ for Hedera and 66.4

$313 \mathrm{mmol} \mathrm{m} \mathrm{s}^{-1}$ for Bergenia. 
314 When measured on the hottest days, Stachys consistently had the lowest leaf surface

315 temperature amongst all species, both under 'well- watered' and 'dry' regimes (e.g. see data

316 for early afternoon measurement on 3 July 2009, Day 24 of the experiment, Fig. 1). All other

317 species had similar leaf surface temperatures when they were well watered (Fig. 1). In the

318 'dry' treatment the following order of surface temperatures was recorded on 3 July: bare

319 substrate $>$ Hedera $=$ Sedum $>$ Bergenia $>$ Stachys (Fig. 1). There was no significant

320 difference in leaf surface temperature between 'well- watered' and 'dry' Stachys $\left(26.5^{\circ} \mathrm{C}\right.$ vs

$32127.2{ }^{\circ} \mathrm{C}$, respectively, $\mathrm{LSD}=1.25^{\circ} \mathrm{C}$ ). All other surfaces associated with the 'dry' regime

322 were warmer than those 'well-watered' (Fig. 1). Air temperature in the glasshouse

323 compartment at the time when leaf temperatures were measured on 3 July was $30.7^{\circ} \mathrm{C}$.

324 In terms of air temperatures above various surfaces we were only able to establish treatment /

325 species differences on hottest days (air $\mathrm{T}_{\max }>32^{\circ} \mathrm{C}$ ) and only during early afternoons (12:00

$326-16: 00$ h). Air temperatures were lowest above Stachys grown in 'well-watered' treatment

327 and above Sedum in the 'dry' regime (Table 1).

328

329

3.2. Experiment 2. Comparisons between Sedum mix and Stachys byzantina; leaf surface

330 temperature and air temperature above the canopy (glasshouse conditions)

331 In this experiment, there was a difference in SMC between 'well- watered' and 'dry'

332 treatments in both plant species and on bare substrate from Day 4 of the experiment (Fig. 2).

333 Well-watered Stachys and bare substrate SMC was maintained, on average, at least at $0.3 \mathrm{~m}^{3}$

$334 \mathrm{~m}^{-3}$, and Sedum at $0.2 \mathrm{~m}^{3} \mathrm{~m}^{-3}$ (Fig 2). In the 'dry' treatment, Stachys was maintained at

335 around $0.15 \mathrm{~m}^{3} \mathrm{~m}^{-3}$ and Sedum and bare substrate below $0.10 \mathrm{~m}^{3} \mathrm{~m}^{-3}$ (Fig. 2).

336 Leaf stomatal conductance was significantly lower in plants within the 'dry' treatment

337 compared to the 'well-watered' treatment from day 9 in Stachys and Day 16 in Sedum (Fig.

338 3). This was accompanied by the decrease in the instantaneous evaporation (E) in these 
339 species during the same period (data not shown). Over the course of the experiment reducing

340 irrigation decreased $g_{s}$ by $40 \%$ (Stachys) and 50\% (Sedum) (Fig. 3).

341 As in Year 1, leaf temperatures in Stachys on the hottest days (i.e. maximal daytime

342 temperature $\left.>30^{\circ} \mathrm{C}\right)$ were similar in 'well- watered' and 'under-watered' plants (27.8 vs 28.3

$343{ }^{\circ} \mathrm{C}$ ) and lower in Stachys than in any other surface/watering combination (Fig. 4). Surface

344 temperatures were also higher in 'dry' substrate and Sedum compared to the 'well-watered'

345 equivalents (Fig. 4).

346 Significant differences in air temperatures above the surfaces were only detected on the

347 hottest day of the experiment (21 June 2010, maximal daytime temperature in the glasshouse

348 compartment was $31.5^{\circ} \mathrm{C}$ ) and only during early afternoon (12-16 h); air temperatures were

349 lowest above 'well-watered' Stachys (Table 2).

350

351 3.3. Experiment 3. Comparisons between Sedum mix and Stachys byzantina: leaf surface

352 temperature, air temperature above the canopy and ground surface cooling (outdoor

353 conditions)

354

355 During the outdoor experiment in June 2011 there was extensive cloud cover on many of the

356 days over which the experiment was conducted. According to data from sensors on the

357 experimental site and information from University of Reading's weather station, there were

358 only two days ( $3^{\text {rd }}$ and $4^{\text {th }}$ June) where full sunlight, low wind speeds and warm temperatures

359 (20-25 ${ }^{\circ} \mathrm{C}$ daytime, $10-15^{\circ} \mathrm{C}$ nightie) were consistently recorded (i.e. > 12 hours sunlight).

360 Surface temperatures of plants and substrate outdoors showed identical patterns to that in

361 glasshouse Experiments 1 and 2. For example, during the warmest day of the experiment (4

362 June 2011, Day 8 of the experiment, air $\mathrm{T}_{\max }=25.6{ }^{\circ} \mathrm{C}$ ), temperatures were highest in the

363 bare substrate, followed by Sedum and lowest in Stachys; this was confirmed by both thermal 
364 imaging and temperature sensors (data not shown). We found significant differences in soil 365 temperatures during the warmest part of the day $(12-16$ h). Soil underneath Stachys was 366 over $11^{\circ} \mathrm{C}$ cooler than soil under Sedum, which was also almost $3{ }^{\circ} \mathrm{C}$ cooler than bare 367 substrate in the period $12-16 \mathrm{~h}$ (Table 3). In the same period, air temperatures $100 \mathrm{~mm}$ 368 above Stachys and Sedum were similar (24.8 and $25.1{ }^{\circ} \mathrm{C}$ on average, respectively), but both 369 were significantly lower than over bare substrate $\left(25.9^{\circ} \mathrm{C}\right)$ (Table 3$)$. Significant differences 370 in air temperature above the two plant canopies were observed, however, on other warm 371 days, but only during shorter intervals (e.g. $24.1{ }^{\circ} \mathrm{C}$ vs $25.0^{\circ} \mathrm{C}$ for Stachys and Sedum 372 respectively, between $12: 30$ and $13: 30$ on $3 \mathrm{June}, \mathrm{LSD}=0.57{ }^{\circ} \mathrm{C}, \mathrm{F}$ pr. $=0.002$ ). In terms of 373 the night time air temperatures, there was no difference between the surfaces (data not 374 shown). Night time soil temperatures, however, were about $1{ }^{\circ} \mathrm{C}$ warmer underneath Stachys 375 compared with Sedum and bare soil (14.6, 14.0 and $13.7^{\circ} \mathrm{C}$, respectively, LSD $=0.47^{\circ} \mathrm{C}$, d.f. $376=293$ ) between 3 and 4 June, but not during 4 and 5 June (data not shown).

377 Net radiation was highest above bare soil $\left(665.1 \mathrm{~W} \mathrm{~m}^{-2}\right)$ followed by that over Sedum mix $378\left(552.7 \mathrm{~W} \mathrm{~m}^{-2}\right)$ and lowest over Stachys $\left(523.6 \mathrm{~W} \mathrm{~m}^{-2}, \mathrm{LSD}=13.55 \mathrm{~W} \mathrm{~m}^{-2}\right)$, indicating that 379 Stachys was reflecting back more of the incoming radiation. Leaf area indices were similar in 380 Sedum mix and Stachys (2.29 vs 2.30, respectively).

382 3.4. Experiment 4. The role of leaf hairs in Stachys byzantina in regulating leaf temperature

383 (controlled environment cabinet)

385 Results of the $24 \mathrm{~h}$ controlled environment experiment measuring the impact of hair removal 386 on leaf temperature in Stachys showed that leaf temperature was consistently significantly 387 higher in shaved leaves, compared with controls (hairs left intact) (e.g. at $24 \mathrm{~h}, 23.3{ }^{\circ} \mathrm{C}$ 388 control vs $23.9{ }^{\circ} \mathrm{C}$ in shaved leaves, $\mathrm{LSD}=0.21^{\circ} \mathrm{C}$ ). These temperature differences, 
389 however, were not matched by statistically significant differences in volume of water lost 390 over $24 \mathrm{~h}\left(3.3 \mathrm{~kg} \mathrm{~m}^{-2}\right.$ control compared to $4.3 \mathrm{~kg} \mathrm{~m}^{-2}$ shaved, LSD $\left.2.68 \mathrm{~kg} \mathrm{~m}^{-2}\right)$ or $g_{s}$ (e.g. at 4

$391 \mathrm{~h}, 0.227 \mathrm{mmol} \mathrm{m}^{-2} \mathrm{~s}^{-1}$ control vs $0.192 \mathrm{mmol} \mathrm{m}^{-2} \mathrm{~s}^{-1}$ shaved leaves, LSD $=0.0479 \mathrm{mmol} \mathrm{m}^{-2}$ $\left.392 \mathrm{~s}^{-1}\right)$.

393

\section{4. Discussion}

395

396 Differences in leaf temperatures between species were apparently strongly linked to

397 differences in leaf morphology and physiology of the species being tested. Stachys byzantina

398 retained the lowest leaf surface temperature when exposed to high air temperatures on clear,

399 sunny days (Figure 1). Furthermore, Stachys was the only species where water deficiency did

400 not significantly increase leaf temperature, with temperature differences being $<0.7^{\circ} \mathrm{C}$

401 between 'well- watered' and 'under-watered' plants, despite very large differences in

402 substrate moisture content and leaf stomatal conductance. In contrast, the level of irrigation

403 supplied to other species such as Sedum and Hedera strongly influenced leaf surface

404 temperature, with leaves of plants exposed to the drier regime being as much as $4.5^{\circ} \mathrm{C}$

405 warmer than those of 'well-watered' plants.

406

407 Temperatures of bare, unplanted, substrate were also significantly affected by moisture

408 content, with 'well-watered' substrates always having lower surface temperature than those

409 where irrigation had been restricted, clearly demonstrating the cooling influence of

410 evaporation alone. The ability for plants to provide additional surface cooling again appeared

411 to be influenced by species choice. Leaf surface temperatures of Stachys plants held under

412 'well-watered' conditions were lower than the surface temperatures of damp bare substrate

413 (Figures 1 and 4). Similarly, 'well-watered' Sedum was also cooler than the watered bare 
414 substrate in Experiment 3 (Figure 4), but surface temperatures of Bergenia and Hedera were

415 little different from that of damp bare substrate (Figure 1). Under the 'dry' conditions,

416 however, leaf temperatures were always lower than those of the bare substrate.

417

418 The relationship between surface temperatures and the air temperature recorded $300 \mathrm{~mm}$

419 above the substrate within the glasshouse environment was more complex. During

420 particularly warm periods, lowest air temperatures were measured above Stachys canopy, but

421 only when the plants were 'well-watered' (Tables 1 and 2). Air temperatures above 'dry'

422 Stachys could be relatively high; note the $7{ }^{\circ} \mathrm{C}$ difference between leaf and air temperature

423 with this treatment in Experiment 1 (compare Figure 1 and Table 1 data). Overall, there were

424 poor correlations between leaf / substrate surface temperatures and air temperatures above the

425 plots. The relatively small plot sizes and the close proximity of the different treatments and

426 subsequent air mixing may partially explain the variability that accounted for this. Although

427 we specifically chose the semi-protected character of the glasshouse to reduce air movement

428 and mixing, there may still have been interference due to thermal gradients associated with

429 the structure of the glasshouse, concrete floors, metal framework etc., as well as neighbouring

430 treatments. In this experiment we also specifically chose to measure temperature at set

431 heights above the substrate, not the plant canopies, and the latter were themselves variable

432 even within a monoculture of the one species. Although we raised the height of the sensors to

433 account for this (100mm above the highest plants), this may have predisposed the sensors to

434 other interfering effects (i.e. greater air movement across the top of the containers, rather than

435 within them). Outdoors, at $100 \mathrm{~mm}$ above ground and over longer averages (e.g. between

$436 \quad 12: 00$ and 16:00 h over two experimental plots) we only detected significant differences in air

437 temperature between vegetation and bare soil, and not between Stachys and Sedum (although

438 the difference was only borderline statistically insignificant). This difference between 
439 vegetated vs non-vegetated (instead of the species difference) was measured consistently

440 during the experiment and in various types of weather. Over shorter intervals on hottest days,

441 however, we found occasional periods when air over Stachys was cooler than over Sedum and

442 we argue that this difference may become important in the scenarios of prolonged hot

443 weather. Even with larger plots, Kjelgren and Montague [33] failed to show any difference in

444 air temperature above two neighbouring areas of grass and asphalt outdoors, due apparently

445 to their close proximity and air mixing (height of measurement was not reported). Other

446 reports though, have detected differences in air temperature above low growing vegetation

447 and hard surfaced areas when measuring at 1 to $2 \mathrm{~m}$ above ground level $[15,16]$. Clearly, the

448 contribution of low growing vegetation to wider aerial cooling effects requires further

449 investigation (especially with respect to air mixing and convection, e.g. [34]), with perhaps

450 effects of vegetated $v s$ non-vegetated areas being more noteworthy than any subtleties due to

451 plant species choice. Nevertheless, plant selection may be more critical at the smaller scale,

452 especially within a few centimetres of the building envelope (where air mixing may be more

453 limited due to parapets, ridge tiles or other structural features), as well as being used to

454 improve the efficiency of mechanical air conditioning units through localized cooling [35].

455 Future work needs to account for confounded factors associated with air movement even a

456 very local levels, however, and more systematic use of sensors placed at discrete distances

457 from the transpiring leaves may be required to determine the 'zone of cooling influence'

458 before air mixing etc. dilutes any effect.

459

460 Of the species we tested, Stachys had the greatest capacity for regulating its own temperature

461 and keeping its leaves cool. It retained the lowest surface temperature even when soil

462 moisture became limited and stomata closed. In the controlled environments utilised in

463 Experiment 4 it was evident that retaining hairs on the leaves of Stachys reduced the amount 
464 of infra-red radiation emitted from the leaf (i.e. the leaves appeared cooler), compared to 465 those leaves where the hairs were trimmed. This cooling conferred by the leaf hairs may be 466 related to light hair colour reflecting or refracting more incoming irradiance [36], and appears

467 to be supported by lower net-radiation values over Stachys which we measured in our 468 experiment. The presence of hairs on leaves has been cited as a mechanism to reduce 469 moisture loss from the leaf surface [37] and / or protect tissues from excessive irradiance, 470 particularly UV wavelengths [38, 39]. In our experiment, although shaved leaves of Stachys 471 lost more water than unshaved ones, differences in moisture loss were not significant. The 472 fact that surface temperatures were significantly different though, may suggest that the 473 predominant role for Stachys hairs is to reduce the intensity of incoming irradiance, provide 474 higher reflectance / albedo and avoid direct heat stress, perhaps with any capacity to trap 475 moisture as only a secondary role. Despite the phenomena of being able to lower its leaf 476 temperature irrespective of the irrigation level applied, the ability for Stachys to maximise air 477 cooling was still strongly dependant on moisture being available and water transpiring 478 through its leaves: greatest air cooling corresponding to the presence of the Stachys canopy 479 combined with the stomata being open.

481 The final component we were interested in was the impact of vegetation type on the substrate 482 temperature below the leaf canopy. It is widely acknowledged that the presence of vegetation 483 lowers soil temperatures during the day and, in the case of green roofs, reduces the 484 temperatures of the roof membrane (e.g. [40]) and the building interior underneath the roof 485 (e. g. [18]). However, these measurements are usually made in model scenarios and species 486 (Sedum, turf) and the understanding of how different plant species impact on surface and 487 building temperatures is limited [16, 23, 41]. Measurements of temperatures underneath plant 488 canopies of six species showed that the presence of closed canopies (as opposed to sparser, 
489

490

491

492

493

494

495

496

497

498

499

500

501

502

503

504 Our experiments explore the concepts and general principles that differences in plant

more open canopies) [16] and higher leaf area index [10] was associated with lower surface temperatures during the day. In another study, Petunia coverage reduced soil temperature more than Hedera [23], but the specifics of the mechanism have not been elucidated. In our study, we again observed the most positive results with Stachys, with substrate temperatures below the Stachys canopy being $>11{ }^{\circ} \mathrm{C}$ lower than under Sedum during the warmest periods (Table 3). Extra shading did not appear to account for this, as the LAI of the two species were similar. The presence of leaf hairs which would act to increase energy reflectance from Stachys' leaves, in addition to evapotranspiration, appears to be important for the regulation of temperature by this plant species. The night time temperatures of the substrate underneath the Stachys were only $1{ }^{\circ} \mathrm{C}$ higher than that of the bare substrate and Sedum, while the daytime differences were - as already discussed - much larger. We feel therefore that the overall benefit is in using Stachys. Additionally, if the thermal load onto the building during the day is decreased and reflection increased (as it appears to with Stachys) the night time thermal discomfort of the building residents underneath this roof, on balance, will be smaller. structure and function, which affect plants' regulation of own temperature, can impact the air and surface temperatures. These concepts now have to be validated by further, more applied,

507 field studies. Similarly, more research is required to investigate the impacts of localized

508 cooling on the leaf, substrate surface, immediate air volume etc. on large, city scale effects.

509 Many urban climate models tend to represent vegetation very simply (see [42]) or define it in 510 broad terms; 'grass' / 'trees' with little precision based on species, albedo characteristics or 511 indeed the impacts of a range of environmental factors that influence stomatal behaviour 512 either directly (irradiance, atmospheric $\mathrm{CO}_{2}, \mathrm{O}_{3}$, humidity, leaf temperature, soil moisture 513 availability,[43]) or indirectly (hormonal and hydraulic signalling, [44]). The data presented 
514 here demonstrate that variations in plant phenotype and physiological adaptions within a

515 range of low-growing species can influence cooling effects on leaf, substrate and by

516 inference, building surfaces, if not always consistently and categorically on air temperatures.

517

518 5. Conclusions

519

520 We advocate that the choice of plant species on green roofs should not be entirely dictated by

521 what survives on the shallow substrates of extensive systems, but consideration should be

522 given for supporting those species that provide the greatest eco-system service potential. This

523 includes, perhaps, justifying the additional expense associated with providing a deeper

524 substrate (such as a semi-extensive system) or even supplementary irrigation from a

525 sustainable source. In this study Stachys outperformed the other species under test in terms of

526 leaf surface cooling, cooling the substrate beneath its canopy and even - during short intervals

527 over hottest still periods - the air above the canopy, when soil moisture was not limited. The

528 fact we measured air temperature differences between the species only during the hottest

529 periods of the experiment may be an important point: it suggests that in many cases either

530 vegetation type is fine, but when temperatures begin to peak (and, potentially, the UHI events

531 start to become significant) there is an advantage with Stachys. This is particularly in respect

532 to lowering air temperatures around the building envelope thus potentially reducing cooling

533 demand and decreasing temperatures around air conditioning units, thereby lowering energy

534 consumption. Stachys is unlikely to be as resilient as Sedum in terms of survival in the most-

535 droughty, extensive, green roofs (e.g. 50-100 $\mathrm{mm}$ deep), but is a drought-adapted species in

536 its own right, capable of survival and persistence without additional irrigation in semi-

537 extensive (200 mm depth) systems within Northern Europe [20]. Nevertheless, we are

538 continuing to investigate the sustainable irrigation regimes/systems to support the growth of 
539 such species to help support them under more extreme climates and to understand potential

540 economic impacts of choosing them (i.e. cooling cost reduction vs increased irrigation and

541 maintenance costs). We are also focusing on the importance of leaf colour and

542 thickness/morphology in the energy balance of leaves and the surrounding surfaces. Our

543 future work will incorporate biological and modelling approaches to provide answers about

544 which biological traits, and through what mechanisms, provide the greatest benefits in a more

545 applied context.

546

547 Acknowledgments

548 This work was financially supported by the Royal Horticultural Society (UK) and Fundação

549 para a ciência e tecnologia (Portugal). We are very grateful to Matthew Richardson, Trevor

550 Pitman and Dr James Wagstaffe for technical help. We thank Valerie Jasper, Michael Dawes,

551 Dr Curtis Wood, Dr Anne Verhoef, Dr Mike Dennett, Arun Pontin, Dr Paul Alexander,

552 Rachael Tanner and Mick Buss for help and / or advice during various stages of the project.

553

554 References

555

556 [1] Bowler DE, Buyung-Ali L, Knight TM, Pullin AS. Urban greening to cool towns and

557 cities: A systematic review of the empirical evidence. Landscape and Urban Planning.

558 2010;97:147-55.

559 [2] Pataki DE, Carreiro MM, Cherrier J, Grulke NE, Jennings V, Pincetl S, et al. Coupling

560 biogeochemical cycles in urban environments: ecosystem services, green solutions, and

561 misconceptions. Frontiers in Ecology and the Environment. 2011;9:27-36.

562 [3] Gill SE, Handley JF, Ennos AR, Pauleit S. Adapting cities for climate change: the role of 563 green infrastructure. Built Environment. 2007;33:115-33.

564 [4] Huang YJ, Akbari H, Taha AA, Rosenfeld H. The potential of vegetation in reducing

565 summer cooling loads in residential buildings. Journal of Applied Meteorology.

566 1987;26:1103-16.

567 [5] Murphy JM, Sexton DMH, Jenkins GJ, Boorman PM, Booth BBB, Brown CC, et al. UK

568 Climate Projections Science Report: Climate change projections. Exeter: Met Office Hadley

569 Centre; 2009. 
570 [6] Shashua-Bar L, Tsiros IX, Hoffman M. Passive cooling design options to ameliorate 571 thermal comfort in urban streets of a Mediterranean climate (Athens) under hot summer 572 conditions. Building and Environment. 2012;57:110-9.

573 [7] Chow WTL, Brazel AJ. Assessing xeriscaping as a sustainable heat island mitigation 574 approach for a desert city. Building and Environment. 2012;47:170-81.

575 [8] Grossman-Clarke S, Zehnder JA, Loridan T, Grimmond CSB. Contribution of Land Use 576 Changes to Near-Surface Air Temperatures during Recent Summer Extreme Heat Events in 577 the Phoenix Metropolitan Area. Journal of Applied Meteorology and Climatology. $578 \quad 2011 ; 49: 1649-64$.

579 [9] Gulyás Á, Unger J, Matzarakis A. Assessment of the microclimatic and human comfort 580 conditions in a complex urban environment: Modelling and measurements. Building and 581 Environment. 2006;41:1713-22.

582 [10] Takakura T, Kitade S, Goto E. Cooling effect of greenery cover over a building Energy 583 and Buildings. 2000;31:1-6.

584 [11] Akbari H, Pomerantz M, Taha H. Cool surfaces and shade trees to reduce energy use and 585 improve air quality in urban areas. Solar Energy. 2001;70:295-310.

586 [12] Alexandri E, Jones P. Temperature decreases in an urban canyon due to green walls and 587 green roofs in diverse climates. Building and Environment. 2008;43:480-93.

588 [13] Grimmond SUE. Urbanization and global environmental change: local effects of urban 589 warming. Geographical Journal. 2007;173:83-8.

590 [14] Mueller EC, Day TA. The effect of urban ground cover on microclimate, growth and 591 leaf gas exchange of oleander in Phoenix, Arizona. International Journal of Biometeorology. 592 2005;49:244-55.

593 [15] Yilmaz H, Toy S, Irmak MA, Yilmaz S, Bulut Y. Determination of temperature

594 differences between asphalt concrete, soil and grass surfaces of the City of Erzurum, Turkey. 595 Atmosfera. 2008;21:135-46.

596 [16] Wong NH, Chen Y, Ong CL, Sia A. Investigation of thermal benefits of rooftop garden 597 in the tropical environment Building and Environment. 2003;38:261-70.

598 [17] Jones HG. Plants and microclimate: Cambridge University Press; 1992.

599 [18] Niachou A, Papakonstantinou K, Santamouris M, Tsangrassoulis A, Mihalakakou G.

600 Analysis of the green roof thermal properties and investigation of its energy performance.

601 Energy and Buildings. 2001;33:719-29.

602 [19] Sailor DJ, Hutchinson D, Bokovoy L. Thermal property measurements for ecoroof soils 603 common in the western U.S. Energy and Buildings. 2008;44:1246-51. 
604 [20] Dunnett N, Kingsbury N. Planting green roofs and living walls. Portland: Timber Press, 605 Inc.; 2008.

606 [21] Monterusso MA, Rowe DB, Rugh CL. Establishment and persistence of Sedum spp. and 607 native taxa for green roof applications. HortScience. 2005;40:391-6.

608 [22] Liesecke HJ. Zwiebel- und Knollenpflanzen fuer extensive dachbegruenungen. 609 Stadt+Gruen. 2001;50:133-9.

610 [23] Sendo T, Kanechi M, Uno Y, Inagaki N. Evaluation of Growth and Green Coverage of 611 Ten Ornamental Species for Planting as Urban Rooftop Greening. Journal of the Japanese 612 Society for Horticultural Science. 2010;79:69-76.

613 [24] Lundholm J, MacIvor JS, MacDougall Z, Ranalli M. Plant Species and Functional 614 Group Combinations Affect Green Roof Ecosystem Functions. Plos One. 2010;5:e9677.

615 [25] Dunnett N, Nolan A. The effect of substrate depth and supplementary watering on the 616 growth of nine herbaceous perennials in a semi-extensive green roof. Acta Horticulturae. 617 2004;643:305-9.

618 [26] Nagase A, Dunnett N. Drought tolerance in different vegetation types for extensive 619 green roofs: Effects of watering and diversity. Landscape and Urban Planning. 2010;97:31862027.

621 [27] Getter KL, Rowe DB. The role of extensive green roofs in sustainable development. 622 HortScience. 2006;41:1275-85.

623 [28] Jones HG, Stoll M, Santos T, de Sousa C, Chaves MM, Grant OM. Use of infrared 624 thermography for monitoring stomatal closure in the field: application to grapevine. Journal 625 of Experimental Botany. 2002;53:2249-60.

626 [29] Ansari AQ, Loomis WE. Leaf Temperatures. American Journal of Botany. 1959;46:7136277.

628 [30] King CM, Robinson JS, Cameron RW. Flooding tolerance in four 'Garrigue' landscape

629 plants: Implications for their future use in the urban landscapes of north-west Europe?

630 Landscape and Urban Planning. 2012;107:100-10.

631 [31] Chen JM, Black TA. Defining leaf area index for non-flat leaves. Plant, Cell \&

632 Environment. 1992;15:421-9.

633 [32] Weyers JDB, Meidner H. Methods in Stomatal Research. Harlow, UK: Longman

634 Scientific \& Technical; 1990.

635 [33] Kjelgren R, Montague T. Urban tree transpiration over turf and asphalt surfaces.

636 Atmospheric Environment. 1998;32:35-41. 
637 [34] Shashua-Bar L, Pearlmutter D, Erell E. The cooling efficiency of urban landscape 638 strategies in a hot dry climate. Landscape and Urban Planning. 2009;92:179-86.

639 [35] Hall MR. Materials for Energy Efficiency and Thermal Comfort in Buildings

640 Cambridge, UK: Woodhead Publishing Ltd 2010.

641 [36] Ehleringer JR, Mooney HA. Leaf hairs: Effects on physiological activity and adaptive

642 value to a desert shrub. Oecologia. 1978;37:183-200.

643 [37] Grammatikopoulos G, Manetas Y. Direct adsorption of water by hairy leaves of Phlomis

644 fructicosa and its contribution to drought avoidance. Canadian Journal of Botany

645 1994;72:1805-11.

646 [38] Gausman HW, Allen WA. Optical Parameters of Leaves of 30 Plant Species. Plant

647 Physiology. 1973;52:57-62.

648 [39] Grammatikopoulos G, Karabourniotis, G., Kyparissis, A., Petropoulou, Y., Manetas, Y.

649 Leaf Hairs of Olive (Olea europaea) Prevent Stomatal Closure by Ultraviolet-B Radiation.

650 Australian Journal of Plant Physiology. 1994;21:293-301.

651 [40] Teemusk A, Mander U. Greenroof potential to reduce temperature fluctuations of a roof

652 membrane: A case study from Estonia Building and Environment. 2009;44:643-50.

653 [41] He H, Jim CY. Simulation of thermodynamic transmission in green roof ecosystem.

654 Ecological Modelling. 2010;221:2949-58.

655 [42] Lemonsu A, Masson V, Shashua-Bar L, Erell E, Pearlmutter D. Inclusion of vegetation

656 in the Town Energy Balance model for modeling urban green areas. Geosci Model Dev

657 Discuss. 2012;5:1295-340.

658 [43] Damour G, Simonneau T, Cochard H, Urban L. An overview of models of stomatal 659 conductance at the leaf level. Plant, Cell \& Environment. 2010;33:1419-38.

660 [44] Wilkinson S, Davies WJ. Ozone suppresses soil drying- and abscisic acid (ABA)-

661 induced stomatal closure via an ethylene-dependent mechanism. Plant, Cell \& Environment.

662 2009;32:949-59.

663 
664 Figure legends

665

666 Figure 1. Mean surface temperature $\left({ }^{\circ} \mathrm{C}\right)$ of bare substrate and plant leaves on July 3, 2009

667 (Day 24 of the Experiment 1). Vertical bars are mean of nine temperature measurements per

668 container and three containers per plant species/surface, a line represents associated LSD

$669\left(1.25^{\circ} \mathrm{C}\right.$, d.f. $\left.=258\right)$. Measurements were made between 13 and $14 \mathrm{~h}$.

670

671 Figure 2. Substrate moisture content $\left(\mathrm{m}^{3} \mathrm{~m}^{-3}\right)$ of 'well- watered'/ 'wet' and 'under-watered'/

672 'dry' Sedum, Stachys byzantina and bare substrate in Experiment 2 (in 2010). Data are mean

673 of 5 measurements per container and three containers per plant species/surface, a line

674 represents associated LSD. Measurements were made between 9 and $10 \mathrm{~h}$.

675

676 Figure 3. Leaf stomatal conductance to water vapour $\left(g_{s}\right)$ 'well- watered'/ 'wet' and 'under-

677 watered'/ 'dry' Sedum and Stachys byzantina in Experiment 2 (in 2010). Data are mean of 14

678 measurements per container and three containers per plant species/surface; thick and thin

679 lines represent LSDs associated with Stachys and Sedum, respectively. Measurements were

680 made between 10 and $15 \mathrm{~h}$.

681

682 Figure 4. Mean surface temperature $\left({ }^{\circ} \mathrm{C}\right)$ of bare substrate and plant leaves on June 16, 17 and

683212010 (Days 14, 15, and 19 of the Experiment 2). Vertical bars are mean of nine

684 temperature measurements per container and five containers per plant species/surface, a line

685 represents associated $\operatorname{LSD}\left(1.35^{\circ} \mathrm{C}\right.$, d.f. $\left.=809\right)$. Measurements were made between 13 and 14

$686 \mathrm{~h}$. 
687 List of tables

688

689 Table 1. Average air temperature $\left({ }^{\circ} \mathrm{C}\right)$ at fixed height, $300 \mathrm{~mm}$ above the substrate level, on

690 two hottest days of the Experiment 1 (27 and 30 June 2009, Days 16 and 19 of the

691 experiment) between 12 and $16 \mathrm{~h}$. Data are mean of sixteen measurements per species/surface

692 and ranked lowest to highest $\left(\mathrm{LSD}=1.61^{\circ} \mathrm{C}\right.$, d.f. $\left.=159\right)$. The means followed by a different

693 letter are statistically significantly different.

694

695 Table 2. Average air temperature $\left({ }^{\circ} \mathrm{C}\right)$ at fixed height, $300 \mathrm{~mm}$ above the substrate level, on

696 the hottest day of the Experiment 2 (21 June 2010, Day 19 of the experiment) between 12 and

$69716 \mathrm{~h}$. Data are mean of sixteen measurements per species/surface and ranked lowest to

698 highest $\left(\operatorname{LSD}=0.758{ }^{\circ} \mathrm{C}\right.$, d.f. $\left.=95\right)$. The means followed by a different letter are statistically

699 significantly different.

700

701 Table 3. Average soil and air (100 mm above the substrate level, sensor in the centre of the

702 plot) temperatures $\left({ }^{\circ} \mathrm{C}\right)$ associated with different surfaces on the hottest day of the

703 Experiment 3 (4 June 2011, Day 8 of the experiment) between 12 and 16 h. Data are mean of

704 fifty measurements per species/surface and ranked lowest to highest (LSDs are given in the

705 table separately for soil and air temperatures, d.f. $=149$ ). The means followed by a different

706 letter are statistically significantly different.

707 
708

Species/Treatment $\quad$ Air temperature $\left({ }^{\circ} \mathrm{C}\right)$

$\overline{\text { Stachys wet }} \overline{32.2 \mathrm{a}}$

Sedum dry

$32.5 \mathrm{ab}$

Substrate wet

$32.8 \mathrm{abc}$

Hedera wet

$33.4 \mathrm{abc}$

Substrate dry

$33.9 \mathrm{bc}$

Sedum wet

$34.0 \mathrm{bc}$

Bergenia wet

$34.1 \mathrm{bc}$

Bergenia dry

$34.2 \mathrm{c}$

Stachys dry

$34.4 \mathrm{c}$

Hedera dry

$34.4 \mathrm{c}$

LSD (d.f.)

1.61 (159)

709

710 
711

712

Species/Treatment $\quad$ Air temperature $\left({ }^{\circ} \mathrm{C}\right)$

$\overline{\text { Stachys wet }} 33.4 \mathrm{a}$

Substrate wet

$33.7 \mathrm{ab}$

Sedum wet

$34.0 \mathrm{ab}$

Stachys dry

$34.1 \mathrm{ab}$

Sedum dry

$34.3 \mathrm{bc}$

Substrate dry

$35.0 \mathrm{c}$

LSD (d.f.)

$0.76(95)$

713 
714

\begin{tabular}{lll}
\hline Species/surface & Soil & Air \\
& temperature & temperature \\
& $\left({ }^{\circ} \mathrm{C}\right)$ & $\left({ }^{\circ} \mathrm{C}\right) @ 100$ \\
& & $\mathrm{~mm}$ \\
\hline Stachys & $22.2 \mathrm{a}$ & $24.8 \mathrm{a}$ \\
byzantine & & \\
Sedum mix & $34.2 \mathrm{~b}$ & $25.1 \mathrm{a}$ \\
Bare substrate & $37.1 \mathrm{c}$ & $25.9 \mathrm{~b}$ \\
\hline LSD (d.f.) & $1.09(149)$ & $0.32(149)$
\end{tabular}

715 


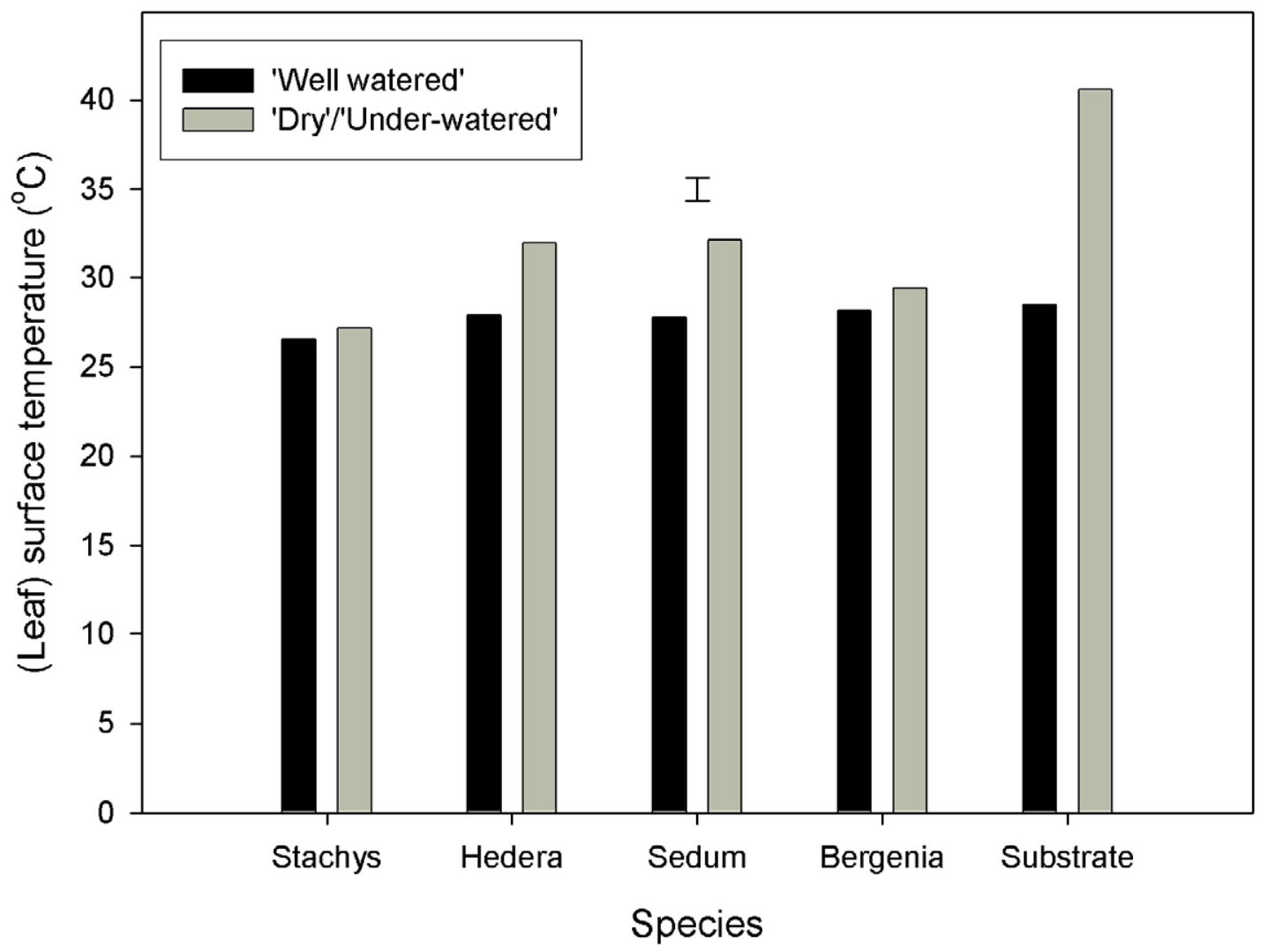




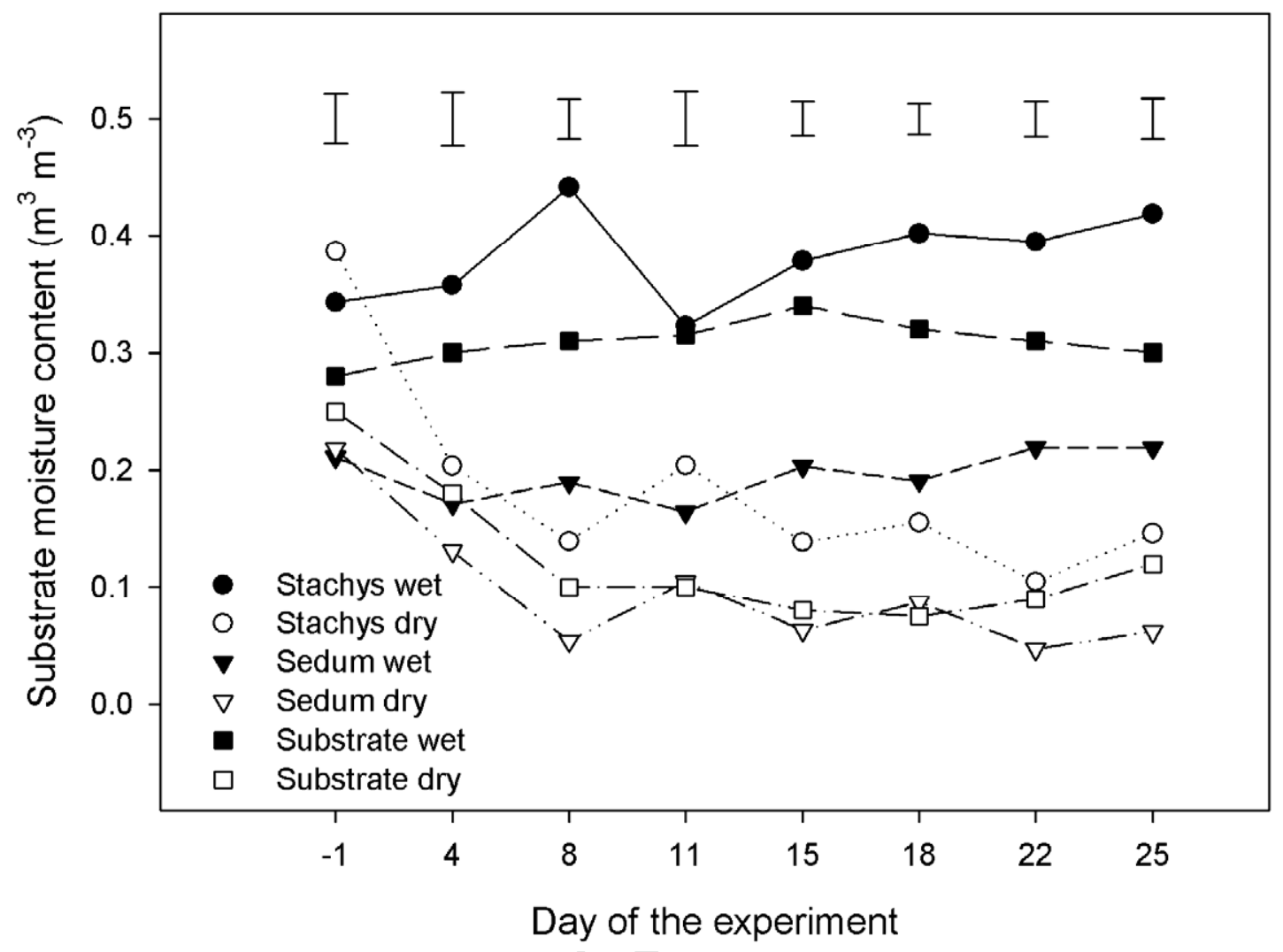




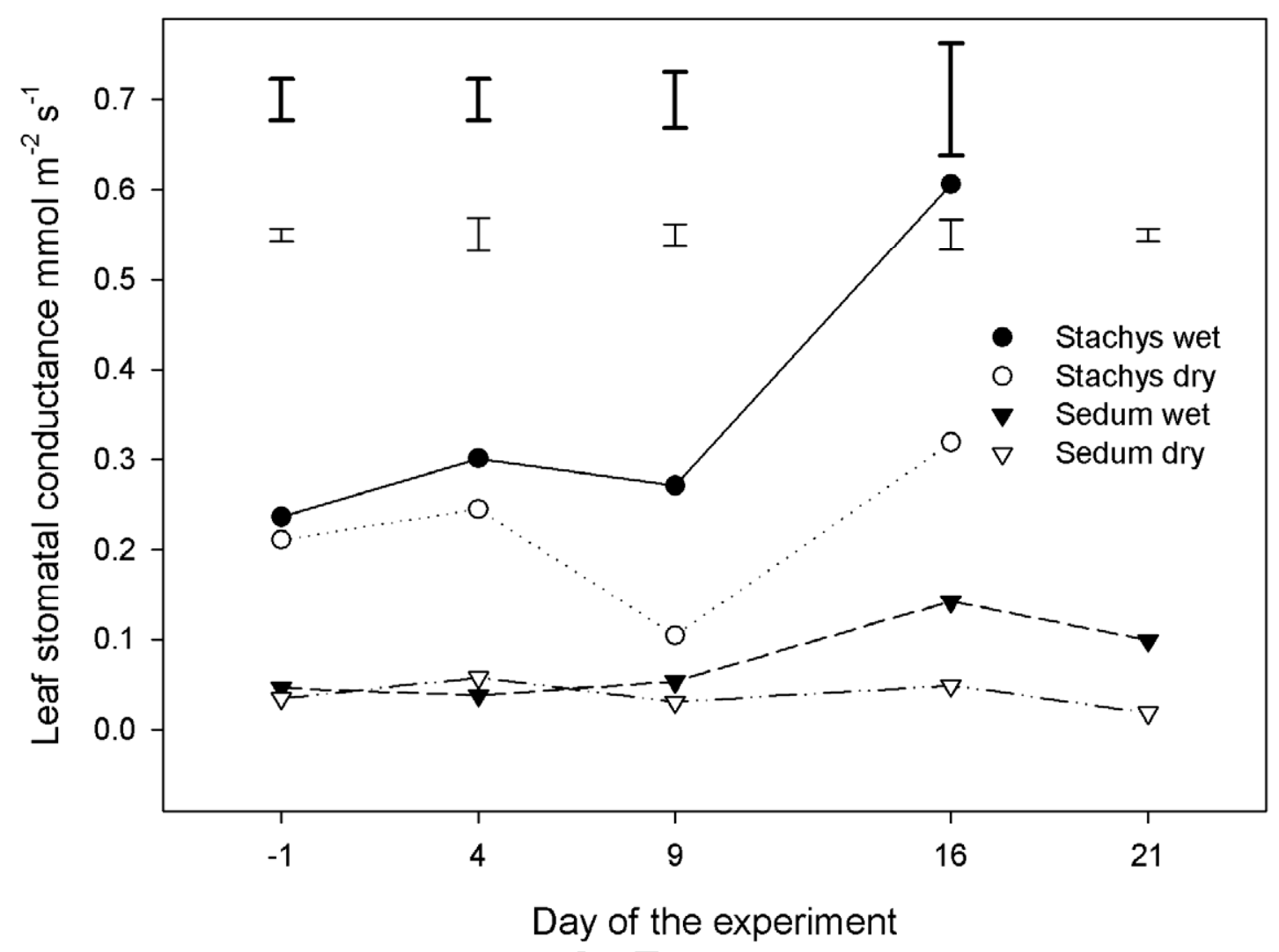




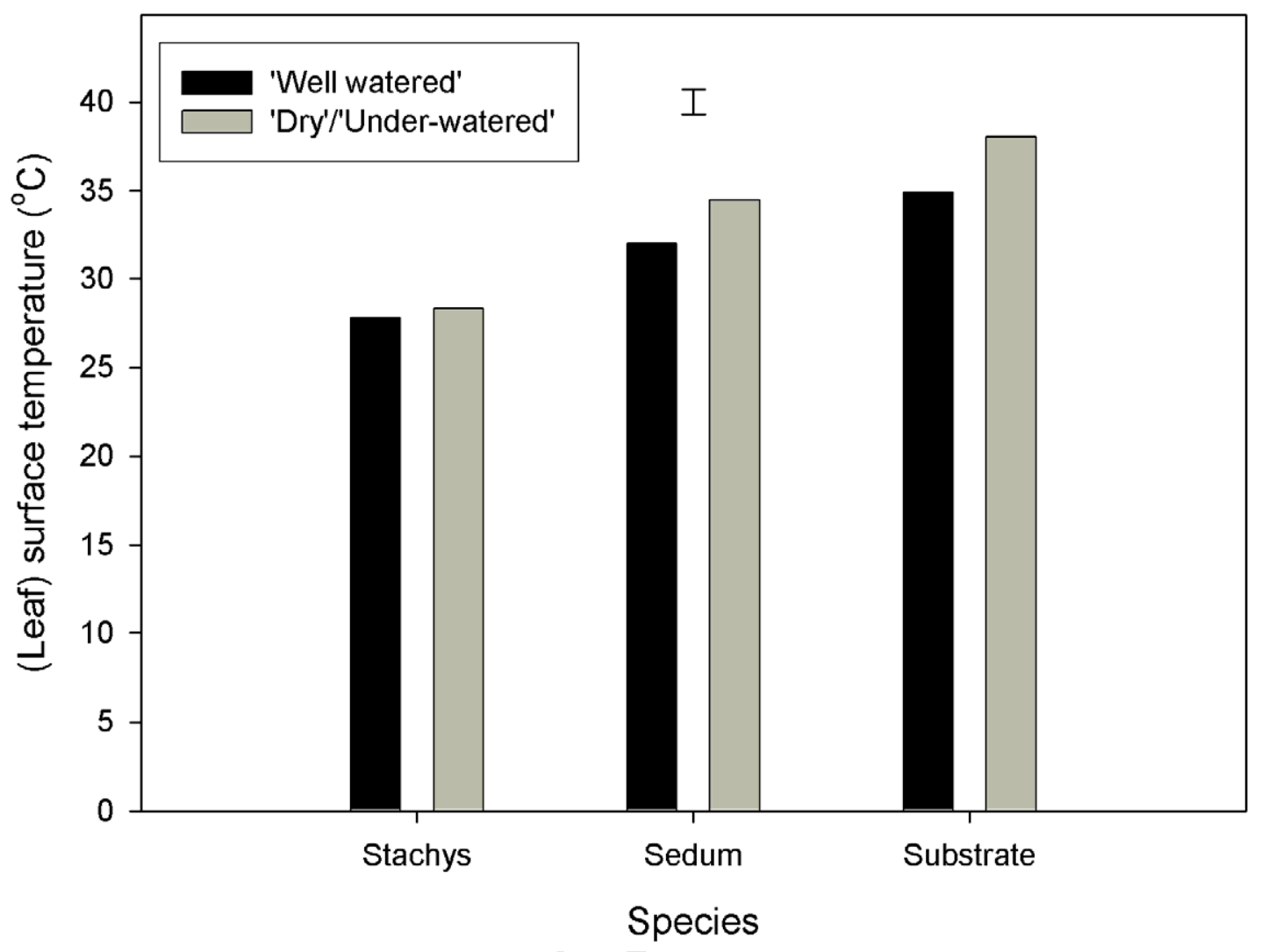

